\title{
Media Pop-Up Book Berbasis Kemampuan Higher Order Thinking Skill (HOTS) pada Daur Hidup Hewan
}

\section{Febriyanti Dwi Lestari ${ }^{*}$, Prima Mutia Sari²}

${ }^{1,2}$ Universitas Muhammadiyah Prof. Dr. Hamka, Jakarta, Indonesia

\section{ART I C L E I N F O}

\section{Article history:}

Received August 26, 2021

Revised August 28, 2021

Accepted September 30, 2021

Available online December 25, 2021

Kata Kunci:

Media Pembelajaran, Pop-up Book, HOTS

Keywords:

Learning Media, Pop-Up Book, HOTS

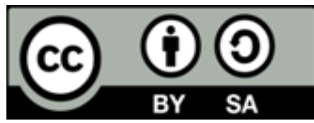

This is an open access article under the CC BY-SA license.

Copyright $(2021$ by Author. Published by Universitas Pendidikan Ganesha.

\begin{abstract}
A B S T R A K
Keterbatasan penggunaan media pembelajan dalam kegiatan belajar mengajar, sehinnga perlu adanya pengembangan media pembelajaran agar tiap peserta didik mampu belajar secara kritis dan mandiri. Keterampilan tersebut penting ditanamkan dalam proses belajar mengajar sebagai landasan untuk menyelesaikan berbagai permasalahan dalam masyarakat di masa yang akan datang. Penelitian ini bertujuan untuk merumuskan dan mengembangkan pop-up book sebagai media pembelajaran pada topik daur hidup hewan. Metode penelitian yang digunakan yaitu menggunakan Research and Development (R\&D) dengan model ADDIE dengan subjek penelitian yaitu 32 siswa dan guru di Sekolah Dasar (SD) Kaliabang Tengah VIII. Metode yang digunakan meliputi observasi, wawancara, dan angket. Instrumen perolehan data yaitu kuesioner dengan skala liktar1-5 dan tes dalam bentuk pilihan ganda. Penelitian ini menemukan bahwa (1) media pop-up book berbasis kemampuan HOTS pengembangan dengan menggunakan model ADDIE melalui 5 tahap yaitu analisis, perencanaan, pengembangan, implementasi dan evaluasi. (2) hasil validasi pop-up book berbasis kemampuan HOTS dari para review dinyatakan valid oleh para ahli, hasil review ahlimateri $98,67 \%$ (sangat baik), hasil review ahli media 90,67\% (sangat baik), hasil review oleh pendidik $92 \%$ (sangat baik), uji coba peserta didik $82,60 \%$ (sangat baik). Dengan demikian media pembelajaran berupa pop-up book berbasis kemampuan HOTS pada IPA dengan topik daur hidup hewan dinyatakan layak digunakan dalam pembelajaran di sekolah dasar. (3) media pop-up book dapat meningkatkan kemampuan berpikir kritis peserta didik tingkatan SD.
\end{abstract}

\begin{abstract}
A BS T R A C T
The limitations of using learning media in teaching and learning activities require learning media development so that each student can learn critically and independently. These skills are essential to be instilled in the teaching and learning process to solve various problems in society in the future. This study aims to formulate and develop a pop-up book as a learning medium on animal life cycles. The research method used is Research and Development (R\&D) with the ADDIE model, with the research subject being 32 students and teachers at the Central Kaliabang VIII Elementary School. The methods used include observation, interviews, and questionnaires. The data acquisition instrument is a questionnaire with a scale of 1-5, and the test is in the form of multiple choice. This study found that (1) pop-up book media based on HOTS capability development using the ADDIE model went through 5 stages: analysis, planning, development, implementation, and evaluation. (2) the results of the pop-up book validation based on the HOTS ability from the reviewers were declared valid by the experts, the results of the material expert reviews were 98,67\% (very good), the results of the media expert reviews were $90.67 \%$ (very good), the results of the reviews by educators $92 \%$ (very good), student trial $82.60 \%$ (very good). Thus the learning media in the form of a pop-up book based on HOTS abilities on the science topic regarding the life cycle is declared suitable for learning in elementary schools. (3) pop-up book media can improve the critical thinking skills of elementary school students.
\end{abstract}




\section{PENDAHULUAN}

Pembelajaran muatan IPA merupakan pembelajaran yang menitikberatkan pada proses ilmiah yang berusaha untuk menganalisis suatu permasalahan tertentu lewat beberapa langkah ilmiah, mulai dari melakukan observasi, merumuskan hipotesis atau kesimpulan sementara, merancang percobaan yang akan dilakukan guna menguji hipotesis yang telah dirumuskan, melakukan percobaan, menafsirkan data dan pengukuran (Priyatma et al., 2019). IPA sebagai produk ilmiah merupakan ilmu pengetahuan yang memuat fakta, hukum, prinsip dan teori yang dapat diuji dan diterima kebenarannya (Marudut et al., 2020). Untuk itu, diperlukan media untuk dapat mempelajari IPA secara menyeluruh. Literasi sains dapat diposisikan sebagai sikap ilmiah yang mengandung nilai dan etika yang penting dalam proses pembelajaran yang meliputi: kemampuan berpikir kritis, rendah hati, curiosity atau rasa ingin tahu yang tinggi, kreatif, pemikiran yang terbuka dengan berbagai hal, mampu menerima kritik dan saran, inovatif, tidak mudah menyerah, dan lain sebagainya (Pertiwi et al., 2018; Prasetiyaningsih, 2019). Dengan diperlukannya literasi sains, peserta didik dapat sensitif terhadap isu-isu global seperti permasalahan lingkungan, kesehatan dan ekonomi, karena dengan pemahaman ilmiah dapat menyelesaikan permasalahan tersebut (Narut, 2018; Narut \& Supradi, 2019; Pertiwi et al., 2018). Pernyataan tersebut jelas menunjukkan bahwa dengan pembelajaran literasi sains peserta didik diharapkan dapat menjalankan tuntutan zaman yang dapat memecahkan masalah dengan kepribadian kompetitif, inovasi, kreativitas, kolaborasi, dan berkarakter. Hal ini dituntut dimiliki oleh peserta didik karena penguasaan keterampilan literasi sains mendukung peserta didik dalam pengembangan dan penggunaan kemampuan abad ke-21 (Yuliati, 2017). Salah satu kemampuan abad ke 21 adalah kemampuan berpikir tingkat tinggi.

Higher Order Thinking Skill (HOTS) adalah kompetensi masa depan diperlukan untuk mengembangkan aktivitasi intelektual dan keterampilan dalam memecahkan suatu permasalahan yang terjadi, memberikan argumen yang kuat pada suatu informasi yang didapatkan, dan mengevaluasi informasi secara merinci pengamatan menggunakan pancaindera, pengalaman yang komprehensif, penalaran, serta komunikasi yang berkorelasi secara signifikan sebagai penentu tindakan (Misrom et al., 2020; Singh \& Marappan, 2020; Yanuarti, 2018). Keterampilan atau kemampuan berpikir tingkat tinggi dapat didentifikasikan sebagai komponen yang krusial dalam proses pembelajaran, khususnya dalam pembelajaran Ilmu Pengetahuan Alamv(IPA) (Jamaluddin et al., 2020; Nugroho \& Airlanda, 2020; Setyawan \& Kristanti, 2021). Kemampuan ini digunakan agar peserta didik mampu mengamati, merumuskan, mengidentifikasi, dan melakukan problem solving atau memecahkan masalah dimulai dengan bahasan bacaan (mendengarkan, mengkritik, dan memilih alternative bacaan), kemudian mengomunikasikan hasil bacaannya di depan kelas dan diskusi, lalu membuat hasil diskusi(Hutabarat, 2019; Setyawan \& Kristanti, 2021). Dalam perkembangannya, partisipasi merupakan faktor yang paling menentukan tercapainya tujuan untuk mengembangkan keterampilan atau kemampuan berpikir kritis pada proses pembelajaran (Malahayati \& Raihan, 2020). Kurangnya partisipasi peserta didik dalam proses pembelajaran membuat tujuan ini sulit dicapai seperti kondisi yang ditemukan dalam pembelajaran daring selama pandemic COVID-19 (Firman \& Rahayu, 2020). Hal ini dikarenakan pembelajaran masih berpusat kepada pendidik dan pendidik hanya menyampaikan informasi dengan metode ceramah, menurunkan keaktifan peserta didik, dan pasif menyalin, duduk, diam mendengarkan dan mengerjakan soal dari pendidik (Izzatul Yuanita, 2020).

Dalam penelitian yang dilakukan The Organization for Economic Co-operation and Development (OECD) untuk menilai kemampuan berpikir tingkat tinggi, peringkat Indonesia di PISA pada tahun 2009 yaitu ke-57 dari 65 dengan peroleh skor 383. Pada tahun 2012 Indonesia menduduki peringkat ke-64 dari total 65 negara dengan perolehan nilai saat itu yaitu 382. Selanjutnya, pada tahun 2015 Indonesia berada pada peringkat ke-64 dari 72 negara yang ikut serta dengan perolehan skor 403 (Argina et al., 2017). Berdasarkan hasil tiga kali survey tersebut, skor peserta didik Indonesia pada kemampuan sains masih jauh di bawah skor standard internasional yang ditetapkan oleh Lembaga OECD. Rendahnya hasil belajar sains disebabkan oleh proses pembelajaran sains yang belum memberikan peluang bagi peserta didik untuk mengembangkan kemampuan berpikir tingkat tinggi dan perlu untuk ditingkat (Robertson, 2021). Kondisi ini tidak terlepas dari proses pembelajaran yang dilakukan. Kondisi ini sesuai studi awal yang dilakukan. Ditemukan bahwa dalam penyampaian materi dalam suatu tema masih kurang maksimal. Pendidik masih menggunakan metode konvensional dan kurang pengaplikasikan media pembelajaran, terutama pada penggunaan media pop-up book dalam proses pembelajaran. Peserta didik tidak diasah rasa ingin tahunya yang bermplikasi pada minimnya pengetahuan peserta didik terhadap materi yang diajarkan. Salah-satu upaya yang dapat dilakukan adalah dengan mengembangkan media pembelajaran.

Media pembelajaran memberikan kesepatan untuk menghasilkan sebuah interaksi yang baik antara siswa dan guru serta membuat proses pembelajaran lebih menyenangkan. (Prastya, 2016; Supriyono, 2018; Windasari \& Sofyan, 2018). Selain itu, adanya model pembelajaran akan mampu meningkatkan minat dalam proses pembelajaran (Tafonao, 2018). Keterlibatan media dalam pembelajaran 
memudahkan proses pemahaman konsep yang akan diajarkan (Budiningsih, 2015; Sinar, 2018; Sundari, 2016). Media pembelajaran dapat menghidupkan suasana kelas pembelajaran yang efektif, mempercepat pemahaman peserta didik, mempercepat proses pembelajaran, menghilangkan rasa bosan peserta didik ketika belajar, dan dapat membuat pembelajaran lebih efisien (Rahmawati et al., 2018). Salah satu media pembelajaran yang digunakan adalah media pop-up book.

Media Pop-up Book dapat didefinisikan sebagai kartu karya seni kertas tiga dimensi yang dapat muncul saat dibuka dan akan terlipat rata saat ditutup (Dini, 2019; Harris Taylor \& Larson Bluemel, 2003; Sinta \& Syofyan, 2020). Pembelajaran dengan media pop-up book membuat peserta didik riang selama pembelajaran berlangsung. Peserta didik dapat dengan mudah diarahkan dan fokus terhadap materi yang disediakan. Media pop-up book dipandang dapat memberikan kesan yang dapat menarik perhatian siswa dan dipandang dapat menumbuhkan semangat belajar peserta didik (Karisma et al., 2020). Beberapa penelitian yang dilakukan sebelumnya antara lain penelitian yang menyatakan bahwa rata-rata skor validasi sebanyak 4,68\% menyatakan bahwa media pop-up book pada materi system tata surya kelas VI SD sangat efektif digunakaan dalam kegiatan belajar mengajar (Sentarik \& Kusmariyatni, 2020). Penelitian lain yang menunjukkan adanya peningkatan yang signifikan dalam penggunaan media pop-up book berbasis tematik dalam meningkatkan hasil belajar peserta didik (Raesita et al., 2019). Penelitian lain tentang pengembangan media pop-up book diperkuat oleh penelitian yang menyatakan bahwa tervalidasi secara keseluruhan dengan perolehan skor keseluruhan 90 dengan persentase sebesar $97.79 \%$, ditetapkan bahwa media pop-up book dalam kriteria "sangat valid". Hal ini menunjukkan bahwa pembelajaran dengan menggunakan media pop-up book dapat mempermudah peserta didik untuk memahami materi Tempat Tinggalku (Dewanti et al., 2018).

Jabaran-jabaran sebelumnya memberikan gambaran bahwa saat ininbelum ada yang mengembngkan mengembangkan media pembelajaran berupa pop-up book berbasis HOTS. Oleh sebab itu, penelitian ini dilaksanakan dengan tujuan menganalisis efektifivitas dari pop-up book sebagai media pembelajaran. Perbedaan pengembangan media Pop-Up Book pada penelitian ini dengan penelitian terdahulu bahwa materi yang diambil merupakan materi daur hidup hewan untuk meningkatkan berpikir tingkat kritis siswa kelas IV SD Negeri Kaliabang Tengah VIII dalam bentuk buku pengayaan yang di dalamnya terdapat narasi untuk menjelaskan materi daur hidup hewan dan belum banyak dikembangkan, sehingga menarik untuk dikembangkan. Kelebihan media yang akan dikembangkan terletak pada segi kualitas media dan materi yang mendukung pengembangan keterampilan HOTS.

\section{METODE}

Jenis penelitian ini adalah penelitian Research and Development (R\&D). Penelitian yang dilakukan menggunakan model ADDIE. Model ADDIE merupakan akronim dari Analyze, Design, Development, Implementation dan Evaluate (Kurnia et al., 2019; Tegeh \& Kirna, 2013). Berikut adalah deskripsi masingmasing tahapan pada penelitian pengembangan model ADDIE. Tahap Analysis model, mencakup: penilaian kebutuhan, identifikas itujuan, tugas, konteks, tujuan, dan analisis keterampilan. Tahap Design mencakup pengembangan tujuan, item tes, dan strategi pembelajaran. Tahap Implementation meliputi kegiatan dalam mendukung pengiriman instruksi. Tahap Evaluation mencakup formatif dan evaluasi sumatif. Hasil akhir dari tahap ini adalah laporan evaluasi dan revisi dari masing-masing tahap untuk digunakan sebagai acuan revisi masing-masing tahapan serta umpan balik secara keseluruhan dari yang telah di buat Adapun flowchat atau bagan penelitian disajikan pada Gambar 1 dan 2.

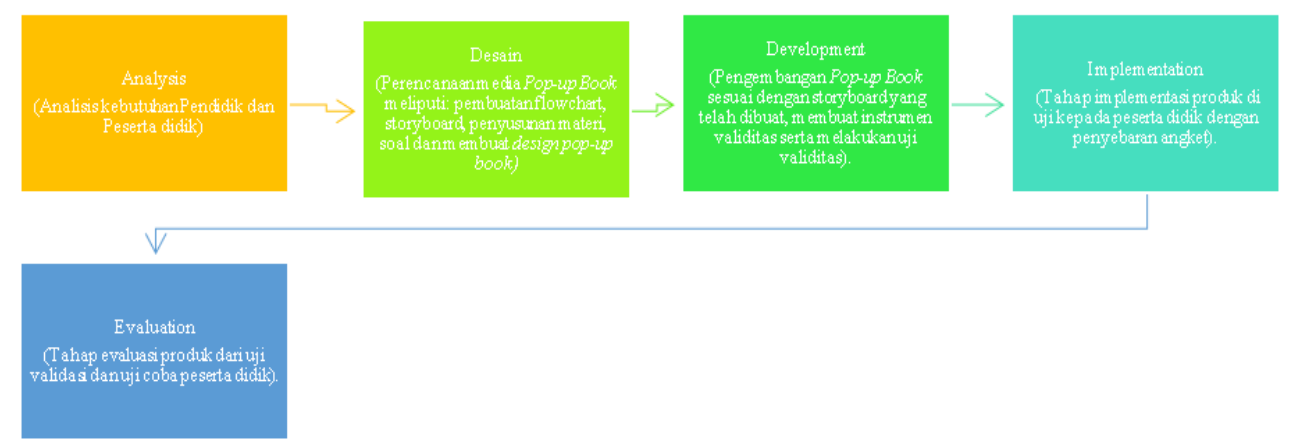

Gambar 1. Flowchart Model Pengembangan ADDIE 


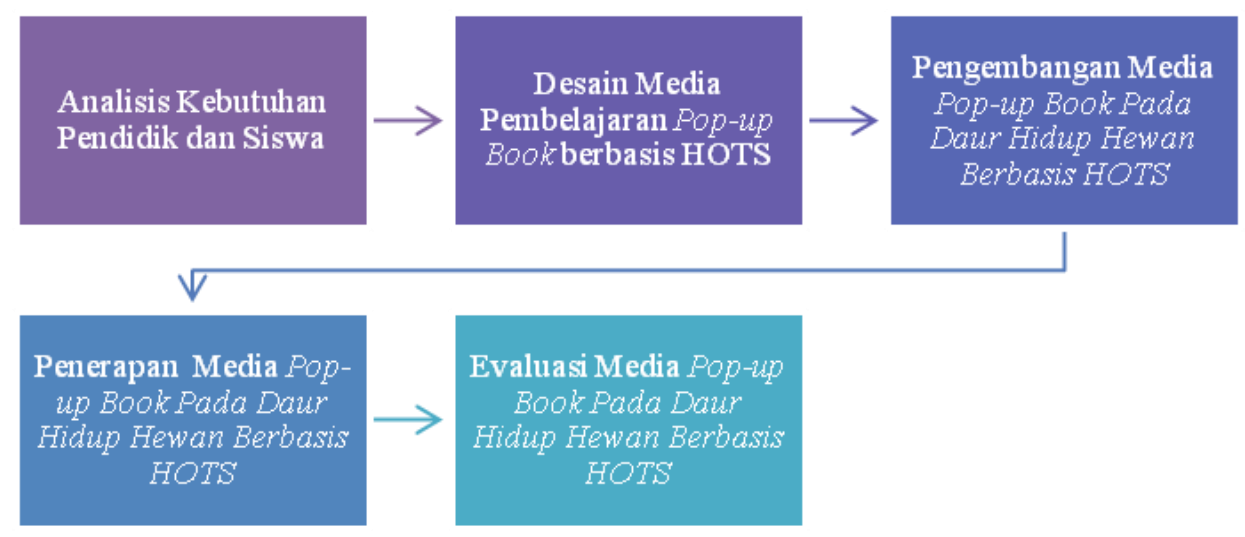

Gambar 2. Flowchart Model Pengembangan ADDIE untuk materi Daur Hidup Hewan

Lokasi penelitian ini yaitu Sekolah Dasar (SD) Negeri Kaliabang Tengah VIII. Data dikumpulkan menggunakan (1) metode observasi dilakukan sebagai langkah awal untuk mengetahui latar belakang dalam penelitian ini; (2) Metode wawancara untuk menganalisis kebutuhan dari peserta didik dan pendidik untuk dijadikan fondasi analisis dalam pembuatan media pop-up book; (3) Metode pengumpulan data berupa angket dilibatkan untuk memvalidasi pop-up book dari berbagai aspek, mulai dari aspek materi, media, dan implementasi atau pelaksanaan pembelajaran (Sinta \& Syofyan, 2020). Metode angket digunakan untuk mengetahui kelayakan media telah ditelaah oleh 1 ahli materi, 1 ahli media, 1 pendidik dan 30 peserta didik; (4) Metode tes digunakan untuk mengetahui efektivitas penggunaan media pembelajaran pop-up book berbasis kemampuan HOTS dalam tema yang diajarkan. Metode ini dilaksanakan pada tahap implementasi dalam bentuk soal pilihan ganda. Instrumen utama untuk mengumpulkan data dalam penelitian ini berupa lembar kuesioner, uji kelayakan, dan soal berupa tes pilihan ganda. Peenelitian R\&D yang dilakukan menggunakan dua teknik analisis yang dilibatkan secara bersamaan yaitu teknik analisis deskriptif kualitatif dan teknik analisis deskriptif kuantitatif. Teknik analisis kualitatif yaitu yang mengelolah data atau review ahli materi dan ahli media berupa saran, masukan dan kritikan (Dianna, 2020). Sedangkan teknik analisis kuantitatif mengelola data instrumen validasi berupa skor dalam bentuk persentase (Dianna, 2020; Prani et al., 2018). Untuk mengetahui kelayakan produk yang dikembangkan disusun kisi-kisi. Adapun kisi-kisi instrument validasi pada Tabel 1.

Table 1. Kisi-kisi Instrumen Validasi

\begin{tabular}{lll}
\hline No. & \multicolumn{1}{c}{ Instrumen } & \multicolumn{1}{c}{ Aspek Penilaian } \\
\hline $1 . \quad$ Validasi Ahli Materi & Aspek Kualitas Isi \\
& & Aspek Indikator HOTS \\
& & Aspek Keterlaksanaan \\
& & Aspek Tampilan Visual \\
2. $\quad$ Validasi Ahli Media & Aspek Kualitas Media \\
& & Aspek Tampilan Media \\
& & Aspek Desain Isi Media \\
3. $\quad$ Uji Kelayakan Pendidik & Aspek Media \\
& & Aspek Pembelajaran \\
4. & Uji Coba Peserta Didik & Aspek Kemenarikan \\
& & Aspek Kualitas Materi \\
\hline
\end{tabular}

\section{HASIL DAN PEMBAHASAN}

Hasil

Dalam mengimplementasikan model ADDIE, dilakukan beberapa tahapan, yaitu analysis, design, development, and implementation. Tahap analisis, dilakukan observasi ke sekolah untuk mencari tahu latar belakang permasalahan yang ada di lapangan terkait kemampuan higher order thinking skill (HOTS) dari peserta didik selama proses pembelajaran yang dialakukan selama ini serta penggunaan media pembelajaran ketika kegiatan belajar mengajar berlangsung. Dari obeservasi dan wawancara ditemukan bahwa peserta didik cenderung mudah merasa jenuh terhadap sistem pembelajaran monoton atau pembelajaran yang mayoritas masih berorentasi pada pendidik. Pendidik pun menyampaikan bahwa kepala sekolah setempat kurang menaruh perhatian terhadap ketersediaan media yang mumpuni untuk menyokong proses pembelajaran yang ada. Inovasi dari pendidik sangat minim, sehingga pendidik masih 
menggunakan media yang sederhana dalam mengajar. Hal ini berimplikasi pada penurunan minat peserta didik dalam proses pembelajaran.

Pendekatan pembelajaran yang hendak dikembangkan telah menggambarkan sebuah proses pembelajaran yang lebih mengedepankan peran aktif peserta didik dalam mengkonstruksi pengetahuan dan keterampilannya. Pendidik lebih banyak menampilkan perannya sebagai pembimbing dan fasilitator belajar peserta didik. Pada materi daur hidup hewan kelas 4 tema 4 subtema 1-4 muatan IPA KD yang tercantum pada kurikulum 2013 yaitu 3.2 Membandingkan siklus hidup beberapa jenis makhluk hidup serta mengaitkan dengan upaya pelestarian. Lebih lengkap disajikan pada Tabel 2, 3.

Table 2. Kompetensi Inti Materi Daur Hidup Hewan

\section{KOMPETENSI INTI}

1. Menerima dan menjalankan ajaran agama yang dianutnya.

3. Memahami pengetahuan factual dengan cara mengamati (mendengar, melihat, membaca) dan menanya berdasarkan rasa ingin tahu tentang dirinya, makhluk ciptaan tuhan dan kegiatannya di rumah dan di sekolah

2. Menunjukkan perilaku jujur, 4. Menyajikan pengetahuan factual dalam Bahasa yang jelas disiplin, tanggung jawab, santun, sistematis dan logis, dalam karya yang estetis dalam gerak yang peduli dan percaya diri dalam mencerminkan anak sehat dan dalam Tindakan yang berinteraksi dengan keluarganya, mencerminkan perilaku anak bermain dan berakhlak mulia teman, guru dan tetangganya.

Table 3. Kompetensi dasar materi daur hidup hewan

\begin{tabular}{ll}
\hline \multicolumn{3}{c}{ KOMPETENSI DASAR } & \multicolumn{1}{c}{ INDIKATOR } \\
\hline 3.2 Membandingkan siklus & 3.2 .1 Menganalisis beberapa jenis daur hidup hewan yang ada di \\
hidup beberapa jenis makhluk & lingkungan sekitar \\
hidup serta mengaitkan & 3.2 .2 Mengidentifikasi beberapa jenis daur hidup hewan di \\
dengan upaya pelestarian & lingkungan sekitar \\
& 3.2.3 Menganalisis upaya pelestarian makhluk hidup yang ada \\
& dilingkungan \\
\hline
\end{tabular}

Setelah kegiatan pembelajaran ini, siswa dituntut memiliki beberapa keterampilan sesuai dengan rumusan tujuan pembelajaran yang telah disusun adalah sebgai berikut. (1) Melalui kegiatan membaca popup book, siswa dapat menganalsis hewan yang mampu bermetamorfisis dengan tepat; (2) Melalui kegiatan pengamatan menggunakan media pop-up book, siswa mampu mengidentifikasi daur hidup hewan yang ada disekitarnya dengan tepat; (3) Melalui kegiatan mengamati daur hidup beberapa jenis hewan menggunakan media pop-up book, siswa mapu membuat kesimpulan tentang daur hidup hewan yang berbeda dengan tepat; dan (4) Melalui membaca teks dongeng, siswa mampu menganalisis upaya pelestarian hewan di sekitar dengan tepat. Tahap perancangan, pada tahap ini dilakukan persiapan seperti 1) pembuatan flowchart, 2) storyboard, 3) materi, 4) pembuatan soal dan 5) desain pop-up book. Alat-alat, bahan-bahan, untuk pembuatan media pop-up book yaitu laptop, print, kertas, gunting, pensil yang digunakan untuk merancang cover, background pada setiap halaman buku, dan gambar pop-up yang diperlukan. Setelah itu, dilakukan perancangan lanjutan dengan merakit media hingga menjadi pop-up book setelah mendapatkan data mengenai kebutuhan dari peserta didik dan pendidik. Terlebih dahulu dirancang desain pop-up book menggunakan aplikasi adobe illustrator dengan teknik floating plane dan open close page. Proses perancangan ditunjukan pada Gambar 3.

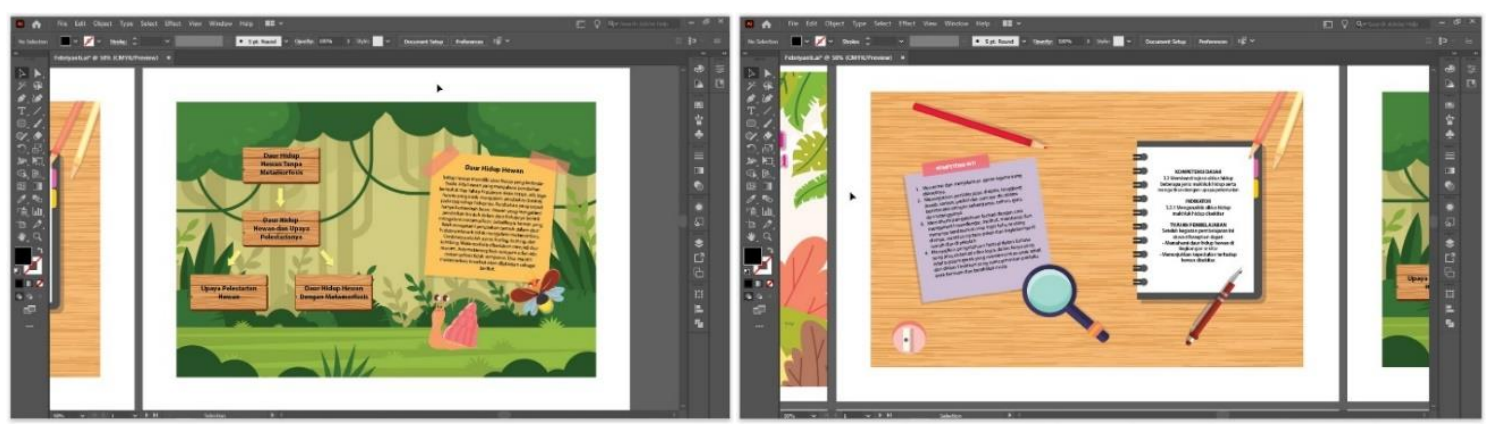

Gambar 3. Perancangan pop-up book 
Tahap ketiga yaitu Pengembangan, kegiatan yang dilakukan pada tahap pengembangan ini, yaitu: 1) pembuatan pop-up book berdasarkan storyboard yang telah dirancang sebelumnya yang berisi materi sesuai kompetensi dasar, kompetensi inti dan soal-soal berbasis HOTS; 2) membuat instrument validitas kelayakan media yang akan dinilai oleh para validator, mulai dari ahli media, ahli media, peserta didik, dan pendidik untuk menguji validasi dan kelayakan; 3) melakukan validasi kepada validator; 4) melakukan uji coba media kepada peserta didik kelas IV untuk mengetahui efektivitas pembelajaran menggunakan media pop-up book terhadap keterampilan atau kemampuan berpikir tinggi terhadap peserta didik. Hasil pop-up book yang berhasil dibuat melalui tahap pengembangan disajikan pada Gambar 4, 5 dan 6 .
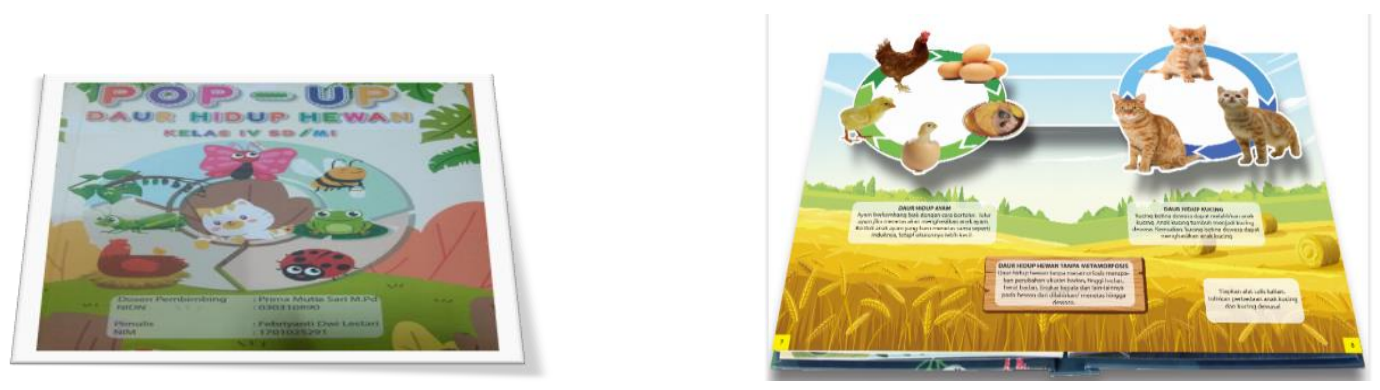

Gambar 4. Hasil Pengembangan Media Pop-up Book Berbasis HOTS

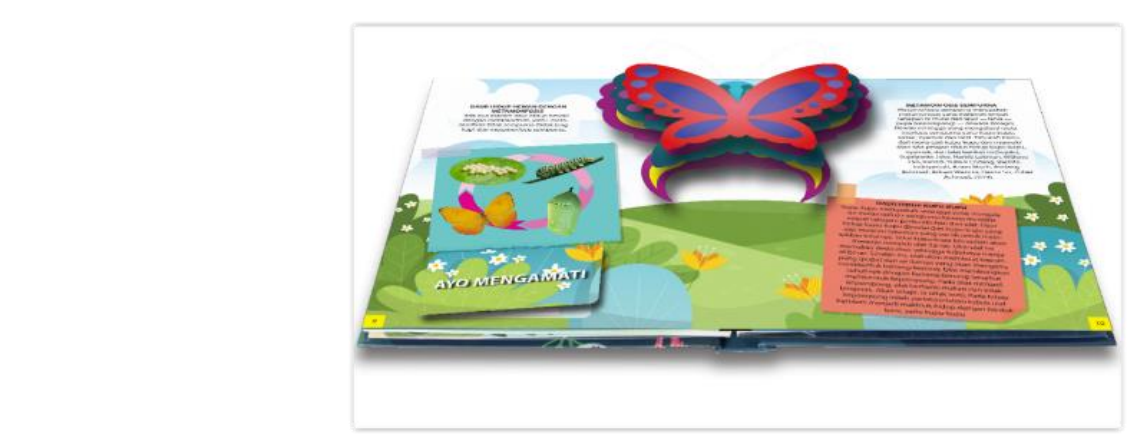

Gambar 5. Tampilan Materi Pada Pop-up Book
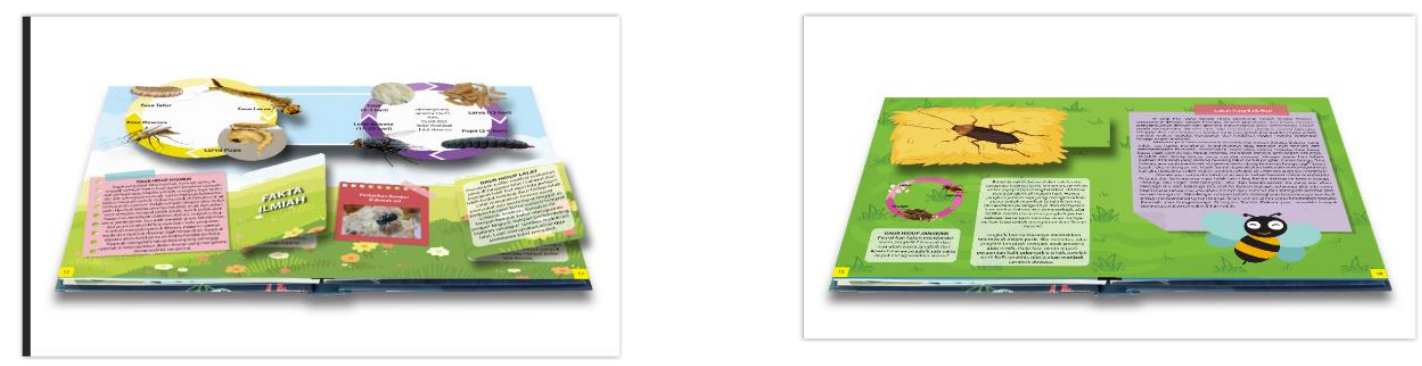

Gambar 6. Tampilan Materi Pada Pop-up Book

Tahap keempat yaitu implementasi media pop-up book berbasis kemampuan berpikir kritis yang telah dikembangkan pada tahap sebelumnya. Tahap ini bertujuan untuk menganalisis respons peserta didik terhadap pengembangan media berupa pop-up book yang diimplementasikan atau diterapkan dalam pembelajaran IPA kelas IV. Tahap kelima yaitu evaluasi yang dilakukan setelah semua tahap sudah dilaksanakan dan memperoleh data berdasarkan dari para validator berupa saran, masukan melalui penyebaran angket, serta melakukan uji kelayakan oleh pendidik dan uji coba kepada peserta didik. Berikut hasil uji validasi oleh ahli materi pada Table 5.

Table 5. Hasil Validasi Ahli Materi

\begin{tabular}{|c|c|c|c|}
\hline No. & Nama Aspek & Hasil Validitas & Kategori \\
\hline 1 & Aspek kualitas isi & $80 \%$ & Baik \\
\hline 2 & Aspek indikator HOTS & $93,33 \%$ & Sangat Baik \\
\hline 3 & Aspek keterlaksaan & $100 \%$ & Sangat Baik \\
\hline \multirow[t]{2}{*}{4} & Aspek tampilan visual & $100 \%$ & Sangat Baik \\
\hline & Total Keseluruhan & $98,667 \%$ & Sangat Baik \\
\hline
\end{tabular}


Dari data tersebut ditemukan bahwa validasi oleh ahli materi meliputi beberapa aspek kualitas isi memperoleh data 80\% dengan kategori baik, aspek indikator HOTS memperoleh data 93,33\% dengan kategori sangat baik, selanjutnya aspek keterlaksanaan memperoleh data $100 \%$ dengan kategori sangat baik, lalu aspek tampilan visual dengan memperoleh data $100 \%$ dengan kategori sangat baik. Selanjutnya hasil validasi ahli media pada Table 6.

Table 6. Hasil Validasi Ahli Media

\begin{tabular}{cccl}
\hline No. & Nama Aspek & Hasil Validitas & \multicolumn{1}{c}{ Kategori } \\
\hline 1 & Aspek kualitas media & $95 \%$ & Sangat Baik \\
2 & Aspek tampilan media & $95 \%$ & Sangat Baik \\
3 & Aspek desain isi media & $85,714 \%$ & Sangat Baik \\
\hline & Total Keseluruhan & $\mathbf{9 0 , 6 7 \%}$ & Sangat Baik \\
\hline
\end{tabular}

Dari data tersebut ditemukan bahwa validasi ahli media memperoleh kriteria "sangat baik" $(90,67 \%)$ sehingga produk media tidak perlu direvisi meliputi aspek kualitas media memperoleh data $95 \%$ dengan kategori sangat baik, aspek tampilan media memperoleh data 95\% dengan kategori sangat baik, dan aspek desain isi media memperoleh data $85,714 \%$ dengan kategori sangat baik. Hasil kelayakan oleh pendidik disajikan pada table 7 .

Table 7. Hasil Uji Kelayakan Pendidik

\begin{tabular}{cccl}
\hline No. & Nama Aspek & Hasil Validitas & \multicolumn{1}{c}{ Kategori } \\
\hline 1 & Aspek media & $88,57 \%$ & Sangat Baik \\
2 & Aspek pembelajaran & $95 \%$ & Sangat Baik \\
\hline & Total Keseluruhan & $\mathbf{9 2 \%}$ & Sangat Baik \\
\hline
\end{tabular}

Berdasarkan data yang diperoleh uji kelayakan pendidik dengan kriteria "sangat baik" (92\%) sehingga media tidak perlu direvisi selaku wali kelas IV A meliputi aspek yaitu aspek media memperoleh data 88,57\% dengan kategori sangat baik, aspek pembelajaran memperoleh data 95\% dengan kategori sangat baik. Hasil uji coba peserta didik terdapat pada Tabel 8.

Table 5. Hasil Uji Coba Peserta Didik

\begin{tabular}{|c|c|c|c|}
\hline No & Nama Aspek & Hasil Validitas & Kategori \\
\hline 1 & Aspek Kemenarikan & $82,44 \%$ & Sangat Baik \\
\hline 2 & Aspek kualitas materi & $82,83 \%$ & Sangat Baik \\
\hline & Total Keseluruhan & $82,60 \%$ & Sangat Baik \\
\hline
\end{tabular}

Hasil data yang diperoleh bahwa uji coba kepada peserta didik kelas IV A sebanyak 30 siswa dengan soal tes pilihan ganda dengan persentase pencapaian pada kriteria "sangat baik" $(82,60 \%)$, sehingga produk media pop-up book berbasis kemapuan HOTS tidak perlu direvisi. Terdapat aspek kemenarikan memperoleh data 82,44\% dengan kategori sangat baik dan aspek kualitas materi memperoleh data 82,83\% dengan kategori sangat baik.

\section{Pembahasan}

Hasil penelitian menunjukkan bahwa pengembangan media pop-up book berbasis kemampuan higher order thinking skill pada materi daur hidup hewan dinyatakan layak digunakan peserta didik dalam kegiatan belajar mengajar. Pengembangan media ini menarik, Kemenarikan media pop-up book berbasis kemampuan HOTS dapat memengaruhi pemahaman peserta didik, menambah pengalaman baru bagi peserta didik dan meningkatkan berpikir kritis peserta didik. Perkembangan dalam hal pemahaman peserta didik dikarenakan oleh: 1) kemenarikan desain pop-up book, sehingga membangkitkan rasa ingin tahu peserta didik; 2) perbedaan tampilan media pop-up book dari media pembelajaran yang lain dapat menarik perhatian peserta didik; 3) penggunaan berbagai warna dalam media pop-up book memudahkan tercapainya tujuan pembelajaran; 4) media pop-up book mudah dibawa kemana saja; 5) media pop-up book mempermudah pesera didik memahami materi daur hidrp hewan. Dari penjabaran tersebut dapat disimpulkan bahwa pengembangan media pop-up book berbasis kemampuan higher order thinking skill pada materi daur hidup hewan dinyatakan menarik digunakan untuk peserta didik dalam kegiatan belajar mengajar. 
Media pop-up book berbasis kemampuan higher order thinking skill layak dan menarik digunakan peserta didik dalam kegiatan belajar mengajar akan memberikan dampak yang positif terhadap pembelajaran. Media pop-up book pada hakikatnya merupakan media yang menitikberatkan pada keaktifan peserta didik dalam pembelajaran. Hal ini mengindikasikan bahwa media pop-up book sangat efektif digunakan dalam kegiatan belajar mengajar. Dengan menggunakan media pop-up book pun dapat mempermudah peserta didik dalam menerima materi ajar, dapat menemukan jawaban dengan mudah, serta meningkatkan kognitif peserta didik dalam berpikir kritis karena dilampirkan gambar-gambar berupa visualisasi (Benardi, 2018). Media pembelajaran ini bukan saja media pembelajaran edukatif melainkan dapat dijadikan sumber belajar yang inovatif, kreatif, dan menarik. Peserta didik pun mampu memahami materi dengan mudah dan pembelajaran tidak monoton (Firmadani, 2020; Junaidi, 2019; Nurhayati, R. \& Afifah, 2017). Dari temuan tersebut, terdapat beberapa manfaat pop-up book sebagai media pembelajaran, antara lain; (1) menumbuhkembangkan rasa untuk bertanggung jawab terhadap buku yang diberikan. Peserta didik akan terpacu untuk merawat dan menghargai buku yang ada; (2) meransang daya imajinatif peserta didik; (3) membangun dan mengembangkan kreativitas peserta didik; (4) secara interaktif memberikan pengetahuan mengenai pengenalan bentuk; (5) mengembangkan minat baca sejak dini kepada peserta didik. Manfaat penggunaan media pop-up book yang lain yaitu: (1) untuk mendorong minat membaca pada peserta didik dengan mengenalkan buku lewat cara yang menyenangkan;(2) dapat digunakan untuk mengoptimalkan daya berpikir kritis; (3) memudahkan anak dalam menafsirkan suatu hal yang bersifat abstrak melalui gambar yang menarik (Karisma et al., 2020; Sinta, 2018).

Hal ini sesuai dengan teori yang ada mengenai manfaat penggunaan media pembelajaran. Media pembelajaran sangatlah penting atau membantu para pendidik untuk mencapai suatu tujuan pembelajaran. Dengan media pembelajaran, peserta didik terbantu untuk memantapkan pengetahuan dan wawasan serta menghidupkan proses pembelajaran. Selain itu, media pembelajaran memiliki banyak fungsi di antaranya adalah fungsi atensi, fungsi afektif, fungsi kognitif, dan fungsi kompensatoris. Fungsi atensi yaitu menarik dan mengarahkan perhatian siswa untuk berkonsentrasi kepada materi pembelajaran. Fungsi afektif yaitu memberi kenyamanan terhadap peserta didik dan mengunggah emosi dan sikap peserta didik. Fungsi kognitif yaitu memberi pemahaman dan penguatan terhadap informasi atau pesan yang terkandung dalam materi pembelajaran. Fungsi kompensatoris yaitu, memberikan konteks untuk memahami teks, membantu siswa yang lemah dalam membaca, dan mengoordinasikan informasi yang didapat untuk mengingatnya kembali.

Penelitian ini mendukung penelitian terdahulu yang menemukanbahwa manfaat Pop-up book yaitu mengembangkan daya imajinatif dan menambah pengetahuan dengan memanfaatkan gambar, sehingga hal tersebut dapat memicu daya pikir kritis (Benardi, 2018; Dzuanda, 2011; Nurhayati, R. \& Afifah, 2017). Terdapat beberapa perbedaan yang ditemukan antara penelitian dengan penelitian sbelumnya. Penggunaan media pembelajaran ini dapat memudahkan peserta didik dalam mempelajari IPA yang membutuhkan analisis mendalam, terutama dalam materi daur hidup hewan. Ditemukan juga bahwa media ini dapat secara universal dijadikan pilihan media yang inovatif dalam pembelajaran IPA dalam tema daur hidup hewan, sehingga peserta didik tidak jenuh dalam proses pembelajaran. Pengembangan media pop-up book mengimplikasikan pentingnya melibatkan kemandirian peserta didik saat belajar, meningkatkan rasa ingin tahu yang besar dari kemenarikan tampilan media pop-up setiap halaman yang disajikan, pembelajaran yang tidak membosankan, lebih mudah memahami materi daur hidup hewan dan dapat digunakan kapan saja dan dimana saja. Media ini mempermudah pendidik dalam penyampaian materi. Media pop-up book adalah media yang unik dapat menarik minat belajar peserta didik, cocok untuk menumbuhkan kreativitas, dan berpikir tingkat tinggi peserta didik. Jika materi dalam bahan ajar ditampilkan dalam bentuk media pop-up book, maka antusias dan motivasi belajar peserta didik akan terunggah untuk mempelajari bahan ajar tersebut.

\section{SIMPULAN}

Media pop-up book berbasis kemampuan higher order thinking skill pada materi daur hidup hewan dinyatakan layak digunakan oleh peserta didik dalam kegiatan belajar mengajar ,baik dari aspek bahasa, materi, dan desain. Selain layak, media yang dikembangkan juga menarik bagi siswa. Media yang menarik bagi siswa akan membuat siswa belajar lebih aktif dan berdampak terhadap hasil belajar. Direkomdasikan agar pendidik menggunakan media pop-up book berbasis kemampuan higher order thinking skill untuk meningkatakan kemampuan berpikir tingkat tinggi.

\section{DAFTAR RUJUKAN}

Argina, A. W., Mitra, D., Ijabah, N., \& Setiawan, R. (2017). Indonesia PISA Result : What Factors and What 
Should be Fixed? The 1st Educational and Language International Conference Proceedings Center for International Developmentof Unissula.

Benardi, A. I. (2018). Pendidikan Kesiapsiagaan Bencana Tanah Longsor untuk Siswa Anak Usia Dini dengan Metode Dongeng Berbasis Media Pop Up Book di PAUD Dewi Sartika Kecamatan Bergas. Jurnal Pendidikan Geografi, 23(2), 85-93. https://doi.org/10.17977/um017v23i22018p085.

Budiningsih, C. A. (2015). Karakteristik Siswa sebagai Pijakan dalam Penelitian dan Metode Pembelajaran. Jurnal Cakrawala Pendidikan, 1(1), 160-173. https://doi.org/10.21831/cp.v1i1.4198.

Dewanti, H., Toenlioe, A. J. E., \& Soepriyanto, Y. (2018). Pengembangan Media Pop-Up Book untuk Pembelajaran Lingkungan Tempat Tinggalku Kelas IV SDN 1 Pakuaden Kabupaten Ponorogo. Jurnal $\begin{array}{llll}\text { Kajian Teknologi } & \text { Pendidikan, } 221-228 .\end{array}$ http://journal2.um.ac.id/index.php/jktp/article/view/4551.

Dianna, D. N. (2020). Dasar-Dasar Penelitian Akademik: Analisis Data Kualitatif dan Kuantitatif. Jurnal Akuntansi.

Dini, H. (2019). Penerapan Media Pop Up Book untuk Meningkatkan Hasil Belajar Siswa pada Pembelajaran Tematik Kelas IV Di Madrasah Ibtidaiyah Nurul Yaqin Sungai Duren. Nanotechnology, 27(9), 35053515.

Dzuanda. (2011). Design Pop-Up Child Book Puppet Figures Series? Gatotkaca?.Jurnal Library ITS Undergraduate.

Firmadani, F. (2020). Media Pembelajaran Berbasis Teknologi sebagai Inovasi Pembelajaran Era Revolusi Industri 4.0. Prosiding Konferensi Pendidikan Nasional.

Firman, F., \& Rahayu, S. (2020). Pembelajaran Online di Tengah Pandemi Covid-19. Indonesian Journal of Educational Science (IJES). https://doi.org/10.31605/ijes.v2i2.659.

Harris Taylor, R., \& Larson Bluemel, N. (2003). Pop-up books: An Introductory Guide. Collection Building, 22(1), 21-32. https://doi.org/10.1108/01604950310457177.

Hutabarat, R. (2019). ESJ (Elementary School Journal) Volume 9 No. 2 Juni 2019. Deskripsi Implementasi Penilaian Autentik Berbasis High Order Thinking Skills (Hots) dalam Menjawab Tantangan Abad 21 Di Sekolah Dasar Kota Medan, 9(2), 159-169.

Izzatul Yuanita, D. (2020). Penerapan Strategi Pembelajaran Aktif dalam Meningkatkan Motivasi Belajar Aswaja Siswa di Madrasah. Bidayatuna: Jurnal Pendidikan Guru Mandrasah Ibtidaiyah. https://doi.org/10.36835/bidayatuna.v3i1.561.

Jamaluddin, J., Jufri, A. W., Muhlis, M., \& Bachtiar, I. (2020). Pengembangan Instrumen Keterampilan Berpikir Kritis pada Pembelajaran IPA di SMP. Jurnal Pijar Mipa. https://doi.org/10.29303/jpm.v15i1.1296.

Junaidi, J. (2019). Peran Media Pembelajaran dalam Proses Belajar Mengajar. Diklat Review: Jurnal Manajemen Pendidikan Dan Pelatihan. https://doi.org/10.35446/diklatreview.v3i1.349.

Karisma, I. K. E., Margunayasa, I. G., \& Prasasti, P. A. T. (2020). Pengembangan Media Pop-Up Book pada Topik Perkembangbiakan Tumbuhan dan Hewan Kelas VI Sekolah Dasar. Jurnal Ilmiah Sekolah Dasar, 4(2), 121. https://doi.org/10.23887/jisd.v4i2.24458.

Kurnia, T. D., Lati, C., Fauziah, H., \& Trihanton, A. (2019). Model ADDIE untuk Pengembangan Bahan Ajar Berbasis Kemampuan Pemecahan Masalah Berbantuan 3D. Seminar Nasional Pendidikan Matematika.

Malahayati, K., \& Raihan, F. (2020). Pengaruh Partisipasi dalam Diskusi Kelas terhadap Kemampuan Berfikir Kritis (Critical Thinking skills) Peserta Didik SMA Negeri di Kota Langsa. Jurnal Samudra Geografi. https://doi.org/10.33059/jsg.v3i1.1995.

Marudut, M. R. H., Bachtiar, I. G., Kadir, K., \& Iasha, V. (2020). Peningkatan Kemampuan Berpikir Kritis dalam Pembelajaran IPA melalui Pendekatan Keterampilan Proses. Jurnal Basicedu. https://doi.org/10.31004/basicedu.v4i3.401.

Misrom, N. S., Abdurrahman, M. S., Abdullah, A. H., Osman, S., Hamzah, M. H., \& Fauzan, A. (2020). Enhancing Students' Higher-Order Thinking Skills (HOTS) through an Inductive Reasoning Strategy Using Geogebra. International Journal of Emerging Technologies in Learning. https://doi.org/10.3991/ijet.v15i03.9839.

Narut, Y. F. (2018). Efektivitas Modul Sistem Pencernaan Berbasis Nature of Science ( NOS ) dalam Meningkatkan Keterampilan Proses Sains Siswa SMA. Pendidikan Dan Kebudayaan, 10(2), 137-273.

Narut, Y. F., \& Supradi, K. (2019). Literasi Sains Peserta Didik dalam Pembelajaran IPA di Indonesia. Jurnal Inovasi Pendidikan Dasar, 3(1), 61-69.

Nugroho, A. N., \& Airlanda, G. S. (2020). Pengembangan Instrumen Penilaian Keterampilan Berpikir Kritis Pembelajaran IPA Kelas 4 SD. Jurnal Ilmiah Pendidikan Profesi Guru. https://doi.org/10.23887/jippg.v3i3.29712.

Nurhayati, R. \& Afifah, L. (2017). Pengembangan Media Pembelajaran Buku Pop-Up untuk Pembelajaran Karya Sastra Bahasa Jerman di Kelas XI SMA Negeri 1 Tarik Sidoarjo. Journal Deutsch Als 
Fremdsprache in Indonesian, 1(2), 1-8., 1-8.

Pertiwi, U. D., Atanti, R. D., \& Ismawati, R. (2018). Pentingnya Literasi Sains Pada Pembelajaran IPA SMP Abad 21. Indonesian Journal of Natural Science Education (IJNSE), 1(1), 24-29. https://doi.org/10.31002/nse.v1i1.173.

Prani, A. I. E., Parno, P., \& Hidayat, A. (2018). Keterampilan Berpikir Kritis pada Bounded Inquiry Lab: Analisis Kuantitatif dan Kualitatif. Momentum: Physics Education Journal. https://doi.org/10.21067/mpej.v1i1.2217.

Prasetiyaningsih, A. (2019). Meningkatkan Literasi IPA melalui Inovasi Model Pembelajaran Jeng Kelin Gallaw untuk Siswa SMP. Bioma: Jurnal Biologi Dan Pembelajaran Biologi. https: //doi.org/10.32528/bioma.v4i1.2648.

Prastya, A. (2016). Strategi Pemilihan Media Pembelajaran bagi Seorang Guru. Prosiding Temu Ilmiah Nasional Guru VIII Tahun 2016: Tantangan Profesionalisme Guru Di Era Digital.

Priyatma, B., Sikumbang, D., \& Marpaung, R. R. T. (2019). Analisis Kendala Pendidik IPA terhadap Pembelajaran IPA Terpadu di SMP Swasta. Jurnal Bioterdidik.

Raesita, M., Robandi, B., \& Rengganis, I. (2019). Efektivitas Penggunaan Media Pop-Up Berbasis Tematik untuk Meningkatkan Hasil Belajar Siswa SD. Jurnal Pendidikan Guru Sekolah Dasar, 4(1), 114-124. https://doi.org/10.17509/jpgsd.v4i1.20535.

Rahmawati, S., Rahman, Sopandi, W., \& Darmawati, B. (2018). Pop-Up Book in Reading Comprehension Ability Context in Thematic Learning. Journal of Education Research and Evaluation.

Robertson, S. L. (2021). Provincializing the OECD-PISA Global Competences Project. Globalisation, Societies and Education. https://doi.org/10.1080/14767724.2021.1887725.

Sentarik, K., \& Kusmariyatni, N. (2020). Media Pop-Up Book pada Topik Sistem Tata Surya Kelas VI Sekolah Dasar. Jurnal Ilmiah Sekolah Dasar, 4(2), 197. https://doi.org/10.23887/jisd.v4i2.25135.

Setyawan, R. A., \& Kristanti, H. S. (2021). Keterampilan Berpikir Kritis pada Pembelajaran IPA melalui Model Pembelajaran Discovery Learning bagi Siswa Sekolah Dasar. Jurnal Basicedu. https://doi.org/10.31004/basicedu.v5i2.877.

Sinar. (2018). Metode Active Learning- Upaya Peningkatan dan Hasil Belajar Siswa. In Yokyakarta: Deepblish.

Singh, C. K. S., \& Marappan, P. (2020). A Review of Research on the Importance of Higher Order Thinking Skills (HOTS) in Teaching English Language. In Journal of Critical Reviews. https://doi.org/10.31838/jcr.07.08.161.

Sinta. (2018). Pengembangan Media Pop-up Book Pada Pembelajaran IPA di SD. https://doi.org/doi.org/10.21009/JPD.011.25.

Sinta, \& Syofyan, H. (2020). Pengembangan Media Pop-Up Book pada Pembelajaran IPA di SD. Jurnal Pendidikan Dasar.

Sundari, N. (2016). Penggunaan Media Gambar dalam Meningkatkan Keaktifan Siswa dalam Pembelajaran Pengetahuan Sosial di Sekolah Dasar. EduHumaniora / Jurnal Pendidikan Dasar Kampus Cibiru. https://doi.org/10.17509/eh.v5i1.2836.

Supriyono. (2018). Pentingnya Media Pembelajaran untuk Meningkatkan Minat Belajar Siswa SD. $\begin{array}{llll}\text { Edustream: } \quad \text { Jurnal } & \text { Dasar, } & \text { II(1), } & \text { 43-48. }\end{array}$ https://journal.unesa.ac.id/index.php/jpd/article/view/6262/3180.

Tafonao, T. (2018). Peranan Media Pembelajaran dalam Meningkatkan Minat Belajar Mahasiswa. Jurnal Komunikasi Pendidikan, 2(2), 103. https://doi.org/10.32585/jkp.v2i2.113.

Tegeh, I. M., \& Kirna, I. M. (2013). Pengembangan Bahan Ajar Metode Penelitian Pendidikan dengan ADDIE Model. Jurnal IKA.

Windasari, T. S., \& Sofyan, H. (2018). Pengaruh Penggunaan Media Audio Visual terhadap Hasil Belajar IPA Siswa Kelas IV Sekolah Dasar. Jurnal Pendidikan Dasar, 10(4), 6. https://doi.org/DOI: doi.org/10.21009/JPD.0101.01.

Yanuarti, E. (2018). Pemikiran Pendidikan Ki Hajar Dewantara dan Relevansinya dengan Kurikulum 13. Jurnal Penelitian, 11(2), 237-266. https://doi.org/10.21043/jupe.v11i2.3489.

Yuliati, Y. (2017). Literasi Sains dalam Pembelajaran IPA. Jurnal Cakrawala Pendas. https://doi.org/10.31949/jcp.v3i2.592. 